\title{
REFLECTIVE TEACHING TOWARD EFL TEACHERS' PROFESSIONAL AUTONOMY: REVISITING ITS DEVELOPMENT IN INDONESIA
}

\author{
Arif Husein Lubis \\ Universitas Pendidikan Indonesia, Bandung, Indonesia
}

lubis_ah@yahoo.com

First draft received: 30 Dec 2017 Accepted: 15 June 2018 Final proof received: 29 Aug 2018

\begin{abstract}
It has been approximately 25 years that reflective teaching in EFL context, particularly in Asia is encouraged and reviewed. The notable goal emphasizes the teachers' role as critical lifelong learners in or outside the classroom to bring about continuous mutual development between them and the surroundings. Although myriad research-based studies have paid attention to the developmental praxis of reflective teaching, scant published articles highlight the progress of its empowerment process and quality in Indonesia. Thus, this paper will address some points related to how this realm is addressed and developed, reflecting from the preceding and contemporary discussion and its milestone in Indonesia within Asia scope. Furthermore, the envision of future direction is prompted from current portrait, existing challenges, and expectations concerning the theoretical foundation, means and models, ICT integration, and character education toward $21 \mathrm{st}-$ century English teachers' professional autonomy.
\end{abstract}

Keywords: Reflective teaching; teacher education; Indonesian EFL teachers; professional autonomy

To cite this paper (in APA style):

Lubis, A. H. (2018). Reflective teaching toward EFL teachers' professional autonomy: Revisiting its development in Indonesia. International Journal of Education, 11(1), 35-49. doi: http://dx.doi.org/10.17509/ije.v11i1.9400

\section{INTRODUCTION}

The praxis of English language teaching has its own dynamic complexities (Broady, 2002; Prapphal, 2004) and development on methodological philosophy (Richards \& Rodgers, 1986) upon which globalization, advancement of knowledge and ICT, as well as the students' linguistic and demographic diversities (Commins \& Miramontes, 2005) put great influence across Asia countries (Wang, 2011; Musa, Lie, \& Azman, 2012; Chinh, 2013; Kirkpatrick, 2016). Such a status quo, then, keeps reinforcing the educational parties to flourish the quality of the preservice teachers' professional preparation and in-service teachers' professional development. Considering the relationship between such quality flourishment and the principle concept of teaching itself, it obviously pinpoints that the process for humanizing human-beings as one fundamental objective of teaching can only be accomplished through the involvement of deliberate thinking about its design, action, and reflection aspects as a one-stop cyclical process. On the other hand, those establishing their comfort-zone teaching routines without such aforementioned involvement will likely be considered as experiencing the decline of their professional commitment and professionalism (Akbari, 2007).

Teachers are encouraged to have the sense of responsiveness and openmindedness as the requisite to be reflective teachers. Some important characteristics to embrace comprise: professionalism as a lifelong learning; adaptive to the changing 
situations; and responsive to the diverse students' characteristics. However, such encouragement of fostering reflective teaching, as though, becomes the ultimate yet inconclusive agenda within teachers' continuous professional development programs considering inadequate early exposure on the transparencies of doing reflective teaching itself. Consequently, limited experience and understanding in preservice teacher education period result in encountering feeling-lost moment after they get into in-service teacher education period.

Although myriad research-based studies have paid attention to the developmental praxis of reflective teaching, scant published articles highlight the progress of its empowerment process and quality in Indonesia. Prompted from the issue, the present study will provide a critical review on the direction of reflective teaching development in Indonesia reflected from Asia and beyond. This literature review discusses a revisit on its milestone and prospective direction in promoting EFL teachers' self-actualization to realize the ultimate goal of reflective teaching, i.e. gaining professional autonomy. It encompasses an overview of reflective teaching reviewed from its philosophical history and characteristics, the importance of implementing RT, the milestone of research on RT in Indonesia and other Asia countries, and the challenges and expectations of the prospective RT development continuously.

\section{METHOD}

This study employs a qualitative approach with literature review method through document analysis (Leech \& Onwuegbuzie, 2008). The first data source is from the research-based articles in national and international journals in some Asian countries in the last 25 years. Second, the data were taken from the books comprising the current portrait of the Asia-Pacific teachers' professional development from UNESCO, the guideline of teachers' continuous professional development [CPD] in India and Saudi Arabia, and the coverage of teacher education in China. Third, the government documents were used in the forms of modules of Guru Pembelajar (Learning Teachers) and some relevant regulations about teachers' professional development. Each data source is presented sequentially.

\section{DISCUSSION}

\section{Reflective teaching: A longitudinal dialectics}

At least almost for about forty-eight years in the middle of Dewey's (1933) and Schön's (1983) masterpieces on reflection and reflective practitioner, the concept of reflective teaching has not been so debated and popular until the beginning of the 1990s to current circumstances. However, they both have argued that teaching has been considered as a profession in which the reflection itself becomes the heart of every professional activity. What differentiates this concept to other decision-making actions is the involvement of "a consecutive ordering of ideas in such a way that each determines the next as its proper outcome, while each, in turn, leans back on its predecessors (Dewey, 1933, pp. 2-3)." Such definition is then cleared out in a more practical statement by Schön (1983) that reflective practice puts great concern on problem setting as the source of understanding one's experience and performance criticizing the prior traditional assumption of idealists that Technical Rationality is bound in every professional practice as a problem-solving process exalting the one-best means of encountering associated problem (selection from the available means), while fundamentally lacking problem setting as the source of one's proposition (p. 39).

The reflective practice movement started its philosophical and practical expansion to teaching realm particularly in English language classrooms in the 1990s. Profoundly speaking, the introduction of reflective teaching as an approach (Richards \& Lockhart, 2007, p. 1) encompasses an active and continuous recognition (Zeichner \& Liston, 1996, p. 5), critical self-examination, and reflection (Fendler, 2003; Richards \& Lockhart, 2007; Minott, 2009) of own teaching and learning values and beliefs (Zeichner \& Liston, 1996). It becomes the requisite of cyclical problem-solving process comprising of decision making, planning, action (Richards \& Lockhart, 2007), analysis, and anticipatory planning (Kumaravideluli, 2003, p. 10). In its process, teachers involve deliberate thinking, while mirroring experience as a 
disposition to bring about positive changes on their teaching practices in a way beyond instructional techniques and passively routinized procedures (Sze, 1999, p. 133). Such a process is believed to constitute to an evaluation of self-knowledge, own teaching aspects, development of teaching strategies, and implementation of selfmonitoring on the applied changes or adaptation (Richards \& Lockhart, 2007, p. 2).

In tandem with the contemporary discussions on the conceptions and models of reflective teaching, it is worth doing then to consider why such an approach is valuable for foreign language teachers' pedagogical and professional development. Ghaye (2011) provides a general insight that "reflective practice can enhance human flourishing by focusing on the establishment of positive relationships, engagement, emotions, and maintaining the meaning or purpose of life (p. 13)." It is in line with the fundamental concept of reflection as the product of paradigm shifts from seeking the one best method to seeking alternatives and involving wider scopes of language teaching and learning, i.e., cognitivism and behaviorism to post-modernism and social constructivism (Richards, 2008). The thrust of self-awareness and critical thinking in encountering daily-teaching circumstances enriches them to help achieve a better understanding of own teaching and learning milestone quality (Richards \& Lockhart, 2007) and their attitudes toward the profession itself from the accumulation of dialectic clarification upon the substance of their stories (Sze, 1999, p. 147). Such reflective routinized practice will enable foreign language teachers to activate their potentials in wider society as selfempowerment and professional development (Richards \& Lockhart, 2007) resulting in the school's improvement (Minott, 2009).

A long-term commitment from the government to foster RT toward EFL teachers' professional autonomy through its inclusion in teacher education programs is inextricably intertwined. Such encouragement indirectly enhances their adaptive state of readiness in that divergent learning circumstances trigger them for better achievable and measurable learning outcomes (Loughran, 2002, p. 35).
Brookfield (1995) added that the reflective teaching through teacher education promotes comprehension skill upon various teaching approaches to testify the prescribed assumptions about teaching and learning. Then, it determines the future plans and actions. As a result, the process ensures them that English language teachers are not only the knowledge transmitters but the thoughtful inquiryoriented practitioners and researchers as well (Ross, 1987; Beck \& Kosnik, 2001).

\section{The milestone of research on reflective teaching in EFL context}

To the extent dialectic examination still becomes a particular interest among philosophers, the concept of reflective teaching has also propelled many scholars, foreign language analysts, and ELT researchers across countries in Asia to share their scientific findings and evidencebased insights to the light of its significant praxis for 21st-century English as a Foreign Language Teaching (EFLT) development. Myriad contemporary research-based published articles have been recorded in the last 25 years involving fifteen countries, i.e. China, Hong Kong, India, Indonesia, Iran, Japan, Korea, Kuwait, Philippine, Russia, Saudi Arabia, Singapore, Taiwan, Turkey, and Yemen. Considering the debate on how practical and significant the practice of RT is, previous studies reviewed the exploration of applicable modes in fostering RT along with its significance. They include: response journals (Lee, 2008); journal writing associated with reflective thinking ( $\mathrm{Ho}$ \& Richards, 1993); the application of action research (Dehghan \& Sahragard, 2015) in scaffolding in-service teachers' reflection (Chodidjah, 2017); the combination of journal writing and peer observation in fostering reflective practice (Lakshmi, 2014); and the engagement of employing various tools of reflective practice (Fakazli \& Gönen, 2017). Some others explored the implementation of reflective teaching associated with teachers' performance (Fatemipour \& HosseingholiKhani, 2014; Sanopao, 2016) and ELT development in a learner-centered situation (Sharafi \& Rokni, 2014); role of RT for effective teaching (Menon \& Alamelu, 2011); and Systemic Functional Linguistics [SFL]-assisted reflective writing practice for preservice 
teachers (Suaib \& Tohamba, 2017). Most studies' focus is the investigation of teachers' perception on using various means of RT realization in the English language classroom and the disseminative training to foster their abilities on selfinquiry, self-awareness, self-assessment, critical thinking, and lifelong learning competencies.

The second concern is on the measurement of teachers' perceptions, attitudes, capability, and quality. They include: the understanding and assessment of reflective thinking (Lee, 2005); the relationship between the level of teachers' RT performance (Ferdowsi \& Afghari, 2015; Li \& Ye, 2016) and either reflective thinking ability (Negari \& Beiranvand, 2013; Afshar \& Farahani, 2015), conceptions of teaching and learning (Rahimi \& Chabok, 2013), or teachers' burnout (Ghazalbas \& Afghari, 2015). Some others related teachers' reflection to practical capabilities like the inclusion of strategy-based instruction (Jadidi \& Keshavarz, 2013) and classroom management (Sammaknejad \& Marzban, 2016). Other scholars investigated the teachers' reflection profiles (Yeşilbursa, 2011) and levels (Astika, 2014; Ansarin, Farrokhi, \& Rahmani, 2015; Amalia, 2017; Lubis, 2017; Nurfaidah, Lengkanawati, \& Sukyadi, 2017) associated with reflective practice levels (Faghihi \& Sarab, 2016); the milestone of RT in language teacher education programs (Al-Ahdal \& Al-Awaid, 2014); and teachers' beliefs on RT for their professional development (Alfaki, 2014).

It goes through the methodology development in researching reflective teaching and the promotion of RT models within training programs. Interestingly, only Akbari, Behzadpoor, and Dadvand (2010) concerned the instrument development of an English language teaching reflection inventory from Iran. Under quantitative design, they developed their prior inventory of 42 Likert-scale items which comprises six elements of teaching reflection, i.e., practical, cognitive, affective, metacognitive, critical, and moral through the process of piloting and testing employing exploratory and confirmatory data analysis. The data showed that moral element and some items in the affective and practical elements were eliminated leaving out 19 items. Meanwhile, the promotion of RT models included upgrading program and framework on teachers' level of critical reflectivity ( $\mathrm{Ho}$, 2009); RT for ESP scope (Almabekova, 2010; Saylag, 2012); RT on teachers' teaching performance through teacher training program (Lan \& Wang, 2013); and the provision of a particular model (Kayapinar, 2016) namely Reflective Practitioner Development Model (RPDM).

Some studies have also encompassed technology application for implementing RT. They include: the application of online platform for developing reflective practice (Brooke, 2012; 2014); the use of blog (Mynard, 2007) and digital media (Harendita, 2017) as the means of reflection itself and the empowerment of videomediated reflective teaching through professional community (Jalilifar \& Nattaq, 2013). Most of the articles reported on the involvement of ICT as a means of mediating the process of introducing, nurturing, and monitoring RT practice for English language teachers whether in a self-directed environment or in a community-based one. The development and attainment of those aforementioned research have shed light upon the clarity and continuity of RT flourishment and inculcation despite methodological, credible evidence, and technical limitations as the one-stop yet intriguing sides for prospective studies.

Unfortunately, such development and attainment are still questionable and unresolved in Indonesia context due to the limited records on how the foreign language teachers, perceive, behave upon, and utilize various aforementioned reflective teaching modes, concepts, and models within either independent research framework or TE programs initiated by the Indonesian government. They mostly conducted an exploration on how pre or in-service teachers perform their reflective writing through journal writing (Astika, 2014; Nurfaidah, et al., 2017); perceive the concept of RT (Amalia, 2017; Lubis, 2017); and scaffold such practice within ICT (Harendita, 2017), SFL (Suaib \& Tohamba, 2017), and PD training (Chodidjah, 2017) instructions. To conclude, the milestone of research on RT mostly explored teacherlevel capability in which studies on ICT and sustainable reflective model in TE programs remain the focal absence. 


\section{Prospects in fostering RT within TEFLIN praxis: Portrait, challenges, and expectations}

The efforts of the Indonesian government, in this sense Ministry of Education and Culture [MOEC], Ministry of National Education [MNE], and other contributing parties, in accompanying 21stcentury English language teachers' continuous professional development (CPD) have been being initiated. Viewed from its underlying philosophy, three policies become the driving means of promoting teachers' self-awareness to apply RT toward sustainable professional autonomy, namely: The Decree of Ministry of National Education (2007; 2008), and The Decree of MOEC (2014). Fundamentally, under the value of democracy and pluralism, those policies respectively encompass the dissemination of four standard competencies (Suherdi, 2012), i.e., pedagogic, personal, social, and professional competencies for formal school teachers from kindergarten to secondary levels, special education school teachers, and instructors.

Those competencies for instructors of any courses and training programs require more clamor in terms of implementing reflective teaching. The policy mandates that pedagogical competence encompasses the mastery of using media and ICT as well as reflective teaching to enhance learning quality through reflection-for-action and reflection-in-action. Personal competence pinpoints teachers' ability to perform openmindedness upon different views and behaviors and to activate self-autonomy, responsiveness, wisdom, and cooperative characters. Meanwhile, social and professional competencies are bound within the urgency of doing self-development through the continuous reflective teaching which is fostered by doing self-evaluation on self-performance continuously and using ICT as the medium. China, according to Hu's (2005) comprehensive historical review article, the MOE (Department of Development and Planning) in association with SEC) (Department of Planning and Construction) also imposed the Compulsory Education Law and the Teachers Law mandating that decentralization on educational policy and ELT development should be realized considering the emphasis of contemporary progressive ideology, individual development and creativity, and educational exploration. Compared to other Asia countries, i.e. India, Saudi Arabia, Uzbekistan, Mongolia, Republic of Korea, Pakistan, Sri Lanka, China, and Philippines, to mention a few, the Indonesian government's initiatives principally have uniformity with those countries in which school-based professional development will be the fundamental shared goals under the guidance of MOEC, MNE, and associated the Educational Institution for Educational Practitioners [LPTK] under Ministry of Research and Higher Education [MRHE]. On the other side, lack of commitment in maintaining the quality of the teachers' professional development as well as the ICT-based PD programs for equality across regions and demographic diversities is still increasingly demanding compared to Uzbekistan, Mongolia, and Republic of Korea (United Nations Educational, Scientific, and Cultural Organization [UNESCO], 2016).

As the continuum of such principle in promoting English language teachers' CPD and reflective teaching, the transparencies of teacher education programs themselves become another focal target. Some encouraged practices within the Guidelines for Teacher CPD for RMSA in India formulated in 2015, which comprise: training, observation, improvement process, study groups, inquiry or action research, individual-directed activities, and mentoring. The immersion of ICT within the CPD program includes alternatives for distance education approaches for teacher training. Saudi Arabia takes into account mostly on training-oriented practices, i.e., lecture, discussion, visiting other schools or classroom, workshop, programmed learning, brainstorming, role-playing, and case studies (Alghamdi \& Li, 2011). While, China divides the coverage of teacher education for preservice teachers from inservice ones (Hu, 2005). The former courses cover the obligation to self-equip with the competence of implementing technology-and-computer-aided teaching and learning instructions through preparing and organizing ICT-based materials. The latter ones cover the curriculum support programmes for knowledge and 
pedagogical competencies (school teachers) and academic or further higher education pursues (teacher educators or trainers) under constructivism and reflective process and approach.

To address so, the Directorate General of Teachers and Education Personnel under MOEC of Indonesia launched Guru Pembelajar in 2013. This program becomes the realization in response to the Teacher and Lecturer Law (2005) mandating the implementation of teachers' training and development as the actualization of professional educators. In addition, it was raised from the still-low average scores of Teachers' Competency Test [UKGr] in the last two periods of implementation, 47 and 56 , which are under the standard minimum of 60 from the MOEC website (http://sergur.kemdiknas.go.id) on teacher certification. The focal purpose is the enhancement of preservice professional preparation and in-service teachers' (including English language teachers) abilities, attitudes, and skills in performing their professional activities. Different from the aforementioned three Asia countries, this program consists of two main platforms: workshop and training within which either face-to-face or online mode is employed based on the demographic needs. The scenario (p. 21) of such implementation is for the sake of three objectives: (1) disseminating attitudes of Guru Pembelajar; (2) encouraging professional competence; and (3) encouraging pedagogical competence, which can be assessed and evaluated based on the advent indicators of perseverance, insightful capacity, and ingenious attitudes. In so doing, selfreflection becomes the foundation upon the comprehending of subject-related concepts and effective learning management in which exposition, QA session, discussion, forum, hands-on tasks, and practicum integrated within a cyclical training process aim to create a critically reflective learning environment.

In tandem with the program initiation, the team also launched some modules of Guru Pembelajar (MOEC, 2016) in the same year facilitating the four standard competencies and the mandates within the regulations of State Ministry for the Empowerment of State Apparatus and Birocracy Reform (2009) about functional position and credit points for teachers' PD. Concerning reflective teaching, the toolkits consist of some RTrelated materials for all levels of education except kindergarten (MOEC, 2016). The professional competence of kindergarten teachers pinpoints the ability to do selfreflection on their own teaching performance within which teachers' performance assessment form [PKG] is employed as the measurement tool. Meanwhile, elementary (either low or high grade) to senior high teachers will be flourished by the introduction and inculcation of reflective teaching definition along with its three dimensions: reflectionin-action, reflection-on-action, and reflection-about-action as the realization of PKB (called CPD) mandate. To succeed such implementation, video recording, reflective journal, direct spoken reflection, peer-reviewed observation or the other way around, and classroom action research are designed to indulge them to be 21 st-century critically reflective language teaching practitioners. It is in line with what Choi and Lee (2007) proposed regarding a bottom-up model of EFL teacher development for Asia countries based on surveys about teacher qualifications and education programs.

Although the materials are comprehensively provided equipped by case study as well with the inclusion of ICT and teachers' associations and forums as an effort of encouraging collaborative reflection process, limitations are also identified concerning the promotion of RT. They comprise:

- There seems no identified match between the definition of three dimensions with the example since the example only shows how a teacher performs lesson-plan-oriented reflection process. Although stating that reflection about action reviews the ethical, moral, political, economic, sociological, and wider aspects, the included examples and case studies seem not to embrace any of those aspects.

- Teachers are encouraged to understand and apply the materials appropriately without a firm explanation and examples from other resources as well as a clear reflective model or cycle to conduct the learning.

- There is no follow-up action or reflective model or cycle for integrating ICT into 
the reflective teaching materials and exercises.

- There is still a misconception and ambiguous statement on the module stating, "at glance, there is no relationship between self-development and learning reflection (p.8)." On the other hand, the concept of teaching experience disseminated in the materials tends to inform the teachers that it is not a particular and personal issue (p.19).

- They are just inside the program, not possibly maintained inside the individual teacher's heart of teaching since there is no advent cooperation between what the government (e.g., an integrative role model) promotes and what the schools develop afterward. It seems only a oneday training session, not a lifelong reflective development cycle.

- There is no comprehensive conception on how to take a follow-up from the reflection through remedial learning or teaching and CAR since reflection as mentioned before fundamentally requires critical self-inquiry regarding ethical, socio-economic, and political concerns of both the teachers and learners' philosophy of language learning. On the other side, remedial learning or teaching is a top-down evaluation depending mostly on the intellectual results of classroom members.

Some contemporary challenges for now's and future's direction in promoting reflective teaching within teachers' $P D$ programs are then in line with those critics and limitations. The first scope is on defining the term RT as the question raised by Zeichner and Liston (1996, p. 7) that misunderstanding of whether reflective teaching is only thinking about teaching matters or whether any systematic procedure of self-inquiry can assist English language teachers to have reflective thinking. Those still become the detrimental commonplace thought of such definitional and conceptual vagueness and ambiguity (Sze, 1999, p. 145). It automatically leads to unclear formulation on the materials development and exposure within the TE programs. What Akbari (2007, p. 193-197) concerns regarding the quality of the reflective cycle in the current's TE programs might be true that such ELT circles still lack necessary critical dimension. Type of reflection being promoted tends to emphasize memory concentration as the core of wrongly-assisted retrospective evaluation resulting in less attention to personal capabilities of imagination and creativity. Problem identification may not be equipped by not encouraging teachers' sensitivity to review beyond-methodology substances and beyond-school-gate phenomena as well (Ghaye, 2011, pp. 1112). It is because the extent to which investigation on the confluence between teachers' knowledge bases (local or existing knowledge), i.e., personal, institutional, intercultural, contextual, pedagogical, linguistic, and interpersonal ones (Mann, 2005) and self-reflection quality remains untouchable. The third scope is from the teachers' beliefs and attitudes toward RT. The statement 'ignorance is a bliss' gives a great impact on their, novice or experienced, reflection process. Their traditional beliefs of EFLT have been so embedded that busy teacher syndrome (Farrell, 1999, p. 52) induces the desire of neglection to have a critical reflection.

Hence, prospective areas for future direction in promoting sustainable reflective teaching for EFL teachers need to be researched, reviewed, and monitored. For teachers, the exploration of means in implementing RT is worth doing, yet still scant in terms of maximizing self-awareness and self-potentials toward self-directed professional development. To mention a few, some scholars have provided useful insights in terms of journal writing conception (Boud, 2001; Richards \& Lockhart, 2007; Fuller, 2013; Chalikandy, 2014) in whether individual or collaborative modes (Murray, 2010; Trites, 2010); whether unstructured like free writing or structured like autobiographical writing (Romero, 2010), portfolios, and profiles (Zalipour, 2015). Some of them also suggested alternative ways including lessons video-taping or recordings (Richards \& Lockhart, 2007; Fuller, 2013; Chalikandy, 2014); self or peer observation (Murphy, 2001; Richards \& Lockhart, 2007; Chalikandy, 2014); lesson reports, surveys, and questionnaires (Richards \& Lockhart, 2007; Chalikandy, 2014). Some others 
suggested internal or external reflection from colleague or student's feedback (Fuller, 2013; Chalikandy, 2014) or student focus groups (Chalikandy, 2014); CAR (Richards \& Lockhart, 2007); and participation in PD-focused workshops, conferences, and teacher support network or associations locally, nationally, or internationally (Murray, 2010; Reichmann, 2010). Innovations on ICT-based journal writing, such as online discussion board (Jones \& Ryan, 2017) and E-mail journaling are also increasingly being promoted. The rationale of such practices reinforces 21stcentury English language teachers toward constructivist classroom agents. It is characterized by what focal roles they should hold and how active their involvement is along with the students in the learning process, which should be based on constructivist epistemology.

School environment then also becomes the pivotal role in fostering such awareness. Considering the demography of Indonesian schools along with the educational system, they seem to lack autonomy. It is because the practice of reflective teaching until now is like a vertical relationship in which the mandate only comes from the government without encouraging the schools themselves through its principals to self-management of such PD activity. Some aspects of the expected vision are still demanding reflected from Tierney (1988) in Minott (2009, pp. 1118). The first prospective environment is initial and continuous socialization in terms of what roles of either the school staffs or the teachers are assigned to and what reflective activities can be done considering the changing nature of ELT and language learners. Then, provision of on-going maintenance of reflective values within the arranged activities can be maximized through the principals' participation in the embrace and supervision stages in a collaborative atmosphere. The inclusion of ICT as a strategy embracing the concept of multimodality may also aid the promotion of the initiated reflective teaching programs (Kaneko-Marques, 2015). However, it is still in the form of training and education sessions from the central system, not in the schools. The last aspect encompasses the establishment of support for reflective teaching activities from all school members. The availability of access to learning materials development as the realization of applying the concept of whole-school professional development gives considerable influence. It will enable not only the teachers as the focal agents of change but also the schools as the contributing element within the maintenance of their motivation and efforts.

Besides the consideration of adopting an appropriate reflective model along with its procedures, good selection of the available modes should become another agenda; particularly the inclusion of ICT for the success of its implementation. The MOEC and MNE of Indonesia have been concerning the use of technologies as one of the objectives of professional and pedagogical competencies for English language teachers to possess. Unfortunately, such involvement is in fact not blended within the application of selected modes - a case study, peer observation, and reflective journal - to mention a few. Further studies are worth to be conducted under the foci of what ICTbased modes are available and how those modes contribute to the light of RT development through its configuration with the existing and other alternative contemporary modes. Some literature has provided insights on this issue including: the application of critical incidents analysis (Farrell, 2013; Brandenburg \& McDonough, 2017), peer coaching (Richards \& Farrell, 2005), video-stimulated IWB (Schmid, 2011), virtual diaries in distance TE (Bergmann \& da Silva, 2013), and European Portfolio for Student Teachers of Languages [EPOSTL]. It is a document-based reflection on didactic knowledge and skills (Newby et al., 2007) as well as strengths and weaknesses based on the systematic feedback (Dirnberger \& Weitensfelder, 2009 , p. 30). An expansion of such portfolio includes the use of internet-based EPortfolio, such as: twitter tweets, video collage, blogging, and V-logging under the Technological Pedagogical Content Knowledge [TPACK] framework (Mishra \& Koehler, 2006 on the grounding concept; Parkes, Dredger, \& Hicks, 2013 on the rubric transparencies), to mention a few.

Apart from those technical matters, the knowledge bases input for the pre and inservice EFL teachers' CPD should be noticed in the process of TE curriculum 
design and development. Since teaching as a profession regards professional (careeroriented claim, Johnston, 2003) and personal competencies (moral and ethics affairs related to pedagogical capacity interlinked with the wider scopes of language teaching, Mori, 2004) as the heart of that career, the introduction, shaping, and maintenance of both values along with moral dimension as another prospective urgency for the government side should be put into concern (Mann, 2005). At least, seven points asserted by Rossner (1992) including: "language development, counseling skills, assertiveness training, confidence-building, computing, meditation, and cultural broadening" can be used as the initial input to measure. Thus, it cannot be separated from the typology of reflection itself starting from descriptive process to critical evaluation (Jay \& Johnson, 2002) as the product of knowledge bases input. Selfcapacity and self-reflexivity of English language teachers are intriguing to be investigated within the three phases progressively resulting in the coverage of dimensions that are being reflected on. The integration between the typology proposed by Jay and Johnson (2002) and critical dimensions of reflection asserted by Richards and Lockhart (2007) is helpful for the administrators in providing a purposeful and cyclical process of RT-based teacher education.

The last yet not least prospective agenda is the dissemination of reflective characters considering the goal of Guru Pembelajar program previously discussed. It may be the most critical factor contributing to the success of either the government's TE programs or the lifelong self-PD. Unfortunately and undeniably, character education finely keeps concerning the students' world and seems isolated from the objective of individual teacher's attainment within the current TE (based on the framework of 2013 Curriculum). On the other hand, reflective teaching, in this matter, is a lifelong teacher-initiated process of making sense of the nature of ELT and bringing about positive changes to insideand-beyond classroom circumstances (Murray, 2010). Indeed, considering the Teacher and Lecturer Law (2005) through the guideline of Guru Pembelajar, three characters are disseminated, i.e., reflective, responsive, and adaptive to the changing situations. However, neither sustainable linkage nor government regulation is available mandating a collaborative supervision, administration, or follow-up with the participating schools to keep maintaining those characters when the English language teachers must encounter the real circumstances in or outside the classroom. The more detrimental mindset regarding the concept of reflective teaching as the simplicity of looking over the realms of technical teaching while building blocks and resistance to personal, professional, institutional, and socio-political aspects of reflection (Lubis, 2016). Such status quo, until nowadays, may result from the egothreatening circumstances of dynamic and contemporary ELT realms triggered by the state of anxiety, unreadiness, helplessness, and blindly subjective judgment, i.e., hostility upon the classroom challenges, which always immediately demand the teachers to perform reflective actions. The sources of that character deterioration and conservatism are worth to be investigated for further studies. The results may implicate to the portrait of the myths and realities of Indonesian TE programs for EFL teachers regarding its character education progress through the role of schools and individual self-esteem.

One notable 'antidote', which has actually been introduced since 2004, is the practice of classroom action research. The rationale of the inclusion of CAR in the aforementioned four basic competencies is its significant role for personal and professional development (Burns, 2010; Mann, 2015) and students' learning progress (Zalipour, 2015) as part of reflective teaching characterized by exploratory teaching. However, the current debate about the policy underlines the teachers' discussion that teaching and educating activities become the main and utmost duties, while research belongs to the lecturers' one. Feeling burdened by the more demanding mandates of teaching workloads and other duties pertaining to their professional development regards research as complementary, even tertiary duty to accomplish. On the other side, additional roles they should possess, i.e., trained coders, local researchers, and global citizens fundamentally deal with the nature 
of reflective teaching. The MNE regulation (2007) also includes CAR as one of the means of realizing such roles and reflective teaching itself. What Denny (2005, p. 9-10) suggests may be beneficial in terms of what contributing climate to the successful implementation of CAR supervision under TE programs. They comprise: moral and academic support within the culture of trust and collaboration between the teachers, schools, and associated government parties; time management considering the teachers' workloads; secure and confidential atmosphere; role modelling; and collaborative groups and research skills encouragement (see Dana \& YendolHoppey, 2014 on the cyclical process of its implementation). Thus, the integration of these requisites and character education of a 21 st-century reflective practitioner is worth to be prioritized and further investigated.

\section{CONCLUSION AND SUGGESTION}

This paper provides a critical review of both the current portrait and milestone of reflective teaching development for EFL teachers in Indonesia reflected from Asia and wider communities. Its prospective direction considering the challenges as well as expectations reflecting from current limitations and contemporary associated literature is also addressed. It is not an inherent skill or innate capability of any person who is just willing to dedicate $\mathrm{him} /$ herself as an EFL teacher. In addition, its concept is not embracing one firm and absolute framework and dimensions, rather reflexive to subject-specific matters while personal one respecting diversely changing professional, personal, socio-political, cultural, and moral values of EFLT. Thus, the paradigm and focus shifts considering the existing challenges and prospective expectations previously discussed need to be critically revisited, properly addressed, and furtherly monitored for the government in collaboration with the schools and the universities from descriptions of teacher education courses, procedures, and modules to outcomes and development within long-term-effect agenda. The emphasis on teacher education for development through the inculcation of crucial characters within the concept of reflective teaching should also become the driving means of realizing the aforementioned prospective areas of development to a better and everlastingly fostered professional autonomy for 21stcentury pre and in-service EFL teachers.

\section{REFERENCES}

Afshar, H. S., \& Farahani, M. (2015). Reflective thinking and reflective teaching among Iranian EFL teachers: Do gender and teaching experience make a difference? Procedia, Social and Behavioral Sciences, 192, 615-620.

Akbari, R. (2007). Reflections on reflection: A critical appraisal of reflective practices in $\mathrm{L} 2$ teacher education. System, 35, 192-207.

Akbari, R., Behzadpoor, F., \& Dadvand, B. (2010). Development of English language teaching reflection inventory. System, 38, 211-227.

Al-Ahdal, A. A. M. H., \& Al-Awaid, S. A. A. (2014). Reflective teaching and language teacher education programmes: A milestone in Yemen and Saudi Arabia. Journal of Language Teaching and Research, 5(4), 759-768.

Alfaki, I. M. (2014). Professional development in English language teaching: A teachers' view. British Journal of Education, 2(7), 32-49.

Alghamdi, A. H., \& Li, L. (2011). Teachers' continuing professional development programmes in the Kingdom of Saudi Arabia.

http://files.eric.ed.gov/fulltext/ED5268 50.pdf/.

Almabekova, O. A. (2010). Reflective teaching in ESP. Journal of Siberian Federal University, Humanities and Social Sciences, 3(3), 462-475.

Amalia, L. L. (2017). Reflective practice and self identity as parts of professional development: A survey in an EFL tertiary level (Unpublished results).. Retrieved from http://asiatefl2017.uny.ac.id/sites/asi atefl2017.../LIST\%20OF\%20ABSTR ACTS-Uploaded.pdf/.

Ansarin, A. A., Farrokhi, F., \& Rahmani, M. (2015). Iranian EFL teachers' reflection levels: The role of gender, experience, and qualifications. The 
Asian Journal of Applied Linguistics, 2(2), 140-155.

Astika, G. (2014). Reflective teaching as alternative assessment in teacher education: A case study of preservice teachers. TEFLIN Journal, 25(1), 16-32.

Beck, C., \& Kosnik, C. (2001). Reflection-inaction: In defence of thoughtful teaching. Curriculum Inquiry, 31(2), 217-227.

Bergmann, J. C. F., \& da Silva, M. (2013). The reflective process in initial teacher education: Virtual diaries in distance education. Diálogo Educ., 13(40), 999-1020.

Boud, D. (2001). Using journal writing to enhance reflective practice. In L. M. English, \& M. A. Gillen (Eds), Promoting journal writing in adult education. New directions in adult and continuing education, (pp. 9-18). San Francisco: Jossey-Bass.

Brandenburg, R., \& McDonough, S. (2017). Using critical incidents to reflect on teacher educator practice. In Brandenburg, R., Glasswell, K., Jones, M., \& Ryan, J (Eds.), Reflective theory and practice in teacher education: Self-study of teaching and teacher education practices, (pp. 223-236). Singapore: Springer.

Broady, E. (2002). Changes, challenges, and complexity: Recent debates in English language teaching. The Language Learning Journal, 26(1), 62-67.

Brooke, M. (2012). Enhancing preservice teacher training: The construction and application of a model for developing teacher reflective practice online. Open Journal of Modern Linguistics, 2(4), 180-188.

Brooke, M. (2014). Developing the reflective practice capabilities of preservice trainees in TESOL through online means. In X. Deng, \& R. Seow (Eds.), Proceedings the 4th CELC Symposium (pp. 50-60). National University of Singapore, Singapore: National University of Singapore.

Brookfield, S. (1995). Becoming a critically reflective teacher. San Francisco, CA: Jossey Bass.
Burns, A. (2010). Doing action research in English language teaching: A guide for practitioners. New York, NY: Routledge.

Chalikandy, M. A. (2014). Reflection: A tool for professional development. Researchers World, Journal of Arts, Science \& Commerce, 5(3), 117-124.

Chinh, N. D. (2013). Cultural diversity in English language teaching: Learners' voices. English Language Teaching, CCSENET, 6(4), 1-7.

Chodidjah, I. (2017). Reflective practice in professional development training: Action research on in-service English teacher training in a secondary school in East Jakarta (Unpublished doctoral thesis). Indonesia University of Education, Indonesia.

Choi, Y. H., \& Lee, H. W. (2007). A model of English teacher development in Asia based on surveys on teacher qualifications and education programs. The Journal of Asia TEFL, 4(4), 1-34.

Commins, N. L., \& Miramontes, O. B. (2005). Linguistic diversity and teaching. Mahwah, $\mathrm{NJ}$ : Lawrence Erlbaum.

Dana, N. F., \& Yendol-Hoppey, D. (2014). The reflective educator's guide to classroom research: Learning to teach and teaching to learn through practitioner inquiry (3rd ed.). USA: Corwin, Sage.

Day, C. (1993). Reflection: A necessary but not sufficient condition for teacher development. British Educational Research Journal, 19(1), 83-93.

Dehghan, F., \& Sahragard, R. (2015). Iranian EFL teachers' views on action research and its application in their classrooms: A case study. Journal of Teacher Education and Educators, 4(1), 39-52.

Dewey, J. (1933). How we think: A restatement of the relation of reflective thinking to the educative process. Boston: Houghton-Mifflin.

Dirnberger, G., \& Weitensfelder, D. (2009). EPOSTL: A tool for supporting reflection in preservice teacher education. In The Centre for English Language Teaching (Eds.), Proceedings of the Anglistik Conference (pp. 29-32). University of 
Vienna, Vienna: The Centre for English Language Teaching.

Faghihi, G., \& Sarab, M. R. A. (2016). Teachers as reflective practitioners: A survey on Iranian English teachers' reflective practice. The Journal of Teaching Language Skills, 7(4), 5786.

Fakazli, Ö., \& Gönen, S. İ. K. (2017). Reflection on reflection: EFL university instructors' perceptions on reflective practices. $H$. U. Journal of Education, 32(3), 708-726.

Farrell, T. (1999). Understanding reflective teaching. Teaching and Learning, 19(2), 52-63.

Farrell, T. S. C. (2013). Reflective practice in ESL teacher development groups: From practices to principles. London, England: Palgrave Macmillan.

Fatemipour, H., \& HosseingholiKhani, F. (2014). The impact of reflective teaching on the EFL teachers' performance. Journal of Educational and Management Studies, 4(4), 796799.

Fendler, L. (2003). Teacher reflection in a hall of mirrors: Historical influences and political reverberations. Educational Researcher, 32, 16-25.

Fuller, A. (2013). Reflective action in teaching [Figure]. In A. L. Herrell, M. L. Jordan, \& J. W. Eby (Eds.), Teaching in the elementary school: $A$ reflective action approach (6th ed.) (pp. 1-20). New York, NY: Pearson.

Ghaye, T. (2011). Teaching and learning through reflective practice: $A$ practical guide for positive action (2nd ed.). New York, NY: Routledge, Taylor \& Francis Group.

Ghazalbash, N., \& Afghari, A. (2015). Relationship between burnout and reflective teaching among EFL teachers. International Journal of Foreign Language Teaching and Research, 3(12), 41-51.

Grimmett, P. P., MacKinnon, A. M., Erickson, G. L., \& Riecken, T. J. (1990). Reflective practice in teacher education. In R. T. Clift, W. R. Houston, \& M. C. Pugach (Eds.), Encouraging reflective practice in education: An analysis of issues and programs (pp. 20-38). New York, NY: Teachers College Press.
Harendita, R. E. (2017). The use of digital media to facilitate critical reflection in microteaching class (Unpublished results). Retrieved from http://asiatefl2017.uny.ac.id/sites/asi atefl2017.../LIST\%20OF\%20ABSTR ACTS-Uploaded.pdf/.

Ho, B., \& Richards, J. C. (1993). Reflective thinking through teacher journal writing: Myths and realities. Retrieved from http://www.researchgate.net/publicati on/268044907/.

Jadidi, A., \& Keshavarz, M. (2013). The impact of Iranian EFL teachers' reflection on their incorporation of strategy-based instruction. International Journal of Language Learning and Applied Linguistics World, 4(3), 140-148.

Jalilifar, A., \& Nattaq, F. (2013). Reflective teaching in the context of a video club: Nurturing professional relationships and building a learner community. International Journal of Society, Culture \& Language, 1(2), 51-66.

Jay, J. K., \& Johnson, K. L. (2002). Capturing complexity: A typology of reflective practice for teacher education. Teaching and Teacher Education, 18, 73-85.

Johnston, B. (2003). Values in English language teaching. Mahwah, $\mathrm{NJ}$ : Lawrence Erlbaum.

Jones, M., \& Ryan, J. (2014). Successful teacher education: Partnerships, reflective practice and the place of technology. Rotterdam: Sense.

Kaneko-Marques, S. M. (2015). Reflective teacher supervision through videos of classroom teaching. PROFILE Issues in Teachers' Professional Development, 17(2), 63-79.

Kayapinar, U. (2016). A study on reflection in in-service teacher development: Introducing reflective practitioner development model. Educational Sciences: Theory \& Practice, 16(5), 1671-1691.

Kirkpatrick, R. (Ed.). (2016). English language education policy in Asia. Dordrecht: Springer.

Kumaravadivelu, B. (2003). Beyond methods: Macrostrategies for 
language teaching. USA: Yale University Press.

Lakshmi, B. S. (2014). Reflective practice through journal writing and peer observation: A case study. Turkish Online Journal of Distance Education, 15(4), 189-204.

Lan, M. H., \& Wang, K.-P. (2013). The effects of reflective teaching on an intensive teacher training program. Indonesian Journal of Applied Linguistics, 3(1), 81-102.

Lee, H.-J. (2005). Understanding and assessing preservice teachers' reflective thinking. Teaching and Teacher Education, 21, 699-715.

Lee, I. (2008). Fostering preservice reflection through response journals. Teacher Education Quarterly, 117139.

Li, Z., \& Ye, Z. (2016). On reflective teaching of EFL teachers in local universities of China: A case study of Leshan Normal University, Sichuan. English Language Teaching, 9(6), 154-161.

Loughran, J. J. (1996). Developing reflective practitioners: Learning about teaching and learning through modelling. London: Falmer Press.

Loughran, J. J. (2002). Effective reflective practice: In search of meaning in learning about teaching. Journal of Teacher Education, 53(1), 33-43.

Lubis, A. H. (2017). Teaching reflection: A voice from Indonesian EFL teachers. International Journal of English Language Teaching and Linguistics, 2(1), 29-39.

Mann, S. (2005). The foreign language teachers' development. Lang. Teach., 38, 103-118.

Menon, S. U., \& Alamelu, C. (2011). Role of reflective teaching in the evolution of an effective teacher. MJAL, 3(2), 7885.

Ministry of Education and Culture. (2014). Standar kualifikasi dan kompetensi instruktur kursus dan pelatihan (no. 90). Jakarta, Indonesia: Author.

Ministry of Education and Culture. (2016). Guru pembelajar: Pedoman program peningkatan kompetensi (Moda tatap muka, daring, dan daring kombinasi). Jakarta, Indonesia: Directorate
General of Teachers and Educational Practitioners.

Ministry of Justice and Human Rights. (2005). Teacher and Lecturer (no. 14). Jakarta, Indonesia: Author.

Ministry of National Education. (2007). Standar kualifikasi akademik dan kompetensi guru (no. 16). Jakarta, Indonesia: Author.

Ministry of National Education. (2008). Standar kualifikasi akademik dan kompetensi guru pendidikan khusus (no. 32). Jakarta, Indonesia: Author.

Minott, M. A. (2009). Supporting reflective teaching via schools' culture: A framework utilizing Tierney's understands of schools' culture. Education-Line. Retrieved from http://leeds.ac.uk/educol/documents/ 142150.pdf/.

Mishra, P., \& Koehler, M. J. (2006). Technological pedagogical content knowledge: A framework for teacher knowledge. Teachers College Record, 108(6), 1017-1054.

Mori, R. (2004). Personal growth in teacher development: A case study. In $\mathrm{M}$. Swanson, \& K. Hill (Eds.), Proceedings of the JALT 2003 Conference (pp. 155-161). Tokyo: Japan Association for Language Teaching.

Murphy, M. J. (2001). Reflective teaching in ELT. In Marianne C.-M (Ed.), Teaching English as a Second or Foreign Language (pp. 499-514). Boston: Heinle \& Heinle.

Murray, A. (2010). Empowering teachers through professional development. English Teaching Forum, 1, 2-10.

Musa, N. C., Lie, K. Y., \& Azman, H. (2012). Exploring English language learning and teaching in Malaysia. Journal of Language Studies, GEMA OnlineTM, Special Section, 12(1), 35-51.

Mynard, J. (2007). A blog as a tool for reflection for English language learners. Asian EFL Journal, Professional Teaching Articles, 24, 1-10.

National Council of Educational Research and Training. (2015). Guidelines for teacher continuous professional development for RMSA. India: RMSA-TCA. 
Negari, G. M., \& Beiranvand, Z. (2013). Investigating Iranian EFL teachers' reflective teaching and their critical thinking abilities. International Journal of Science and Research, 4(3), 776-782.

Newby, D., Allan, R., Fenner, A.-B., Jones, B., Komorowska, H., \& Soghikyan, K. (2007). European portfolio for student teachers of languages: $A$ reflection tool for language teacher education. Austria: Council of Europe.

Nurfaidah, S., Lengkanawati, N. S., \& Sukyadi, D. (2017). Levels of reflection in EFL pre-service teachers' teaching journal. Indonesian Journal of Applied Linguistics, 7(1), 80-92.

Parkes, K. A., Dredger, K. S., \& Hicks, D. (2013). ePortfolio as a measure of reflective practice. International Journal of ePortfolio, 3(2), 99-115.

Prapphal, K. (2004). A reflection of English teaching. MANUSYA: Journal of Humanities, Special issue, 7, 1-5.

Rahimi, A., \& Chabok, S. (2013). EFL teachers' levels of reflective teaching and their conceptions of teaching and learning. Journal of Advanced Social Research, 3(1), 12-29.

Reichmann, C. L. (2010). Constructing communities of practice through memoirs and journals. In J. Burton, P. Quirke, C. L. Reichmann, \& J. K. Peyton (Eds.), Reflective writing: $A$ way to lifelong teacher learning ( $\mathrm{pp}$. 49-62). USA: TESL-EJ Publications.

Richards, J. C. (2008). Towards reflective teaching. Retrieved from http://www.tttjournal.co.uk/uploads/Fi le/back_articles/Towards_Reflective_ Teaching.pdf/.

Richards, J. C., \& Farrell, T. S. C. (2005). Professional development for foreign language teachers: Strategies for teacher learning. USA: Cambridge University Press.

Richards, J. C., \& Lockhart, C. (2007). Reflective teaching in second language classrooms. USA: Cambridge University Press.

Romero, T. R. S. (2010). Reflecting through autobiographies in teacher education. In J. Burton, P. Quirke, C. L. Reichmann, \& J. K. Peyton (Eds.),
Reflective writing: $A$ way to lifelong teacher learning (pp. 82-95). USA: TESL-EJ Publications.

Ross, D. (1987). Action research for preservice teachers: A description of why and how. Peabody Journal of Education, 64, 131-150.

Rossner, R. (1992). Where there's a will: Facilitating teacher development. Teacher Development Newsletter (IATEFL), 18, 4-5.

Sammaknejad, A., \& Marzban, A. (2016). An analysis of teachers' selfreflection on classroom management. Theory and Practice in Language Studies, 6(1), 84-89.

Sanopao, J. P. (2016). The reflective teaching practices and teaching performance of public secondary English teachers. International Journal of Social Science and Humanities Research, 4(1), 358-367.

Saylag, R. (2012). Self reflection on the teaching practice of English as a second language: Becoming the critically reflective teacher. Procedia, Social and Behavioral Sciences, 46, 3847-3851.

Schmid, E. C. (2011). Video-stimulated reflection as a professional development tool in interactive whiteboard research. ReCALL, 23(3), 252-270.

Schön, D. A. (1983). The reflective practitioner: How professionals think in action. San Francisco: JosseyBass.

Sharafi, S., \& Rokni, S. J. A. (2014). The effect of reflective teaching on preservice teachers' learning and teaching development in a learnercentered situation. International Journal of Language Learning and Applied Linguistics World, 5(4), 4958.

State Ministry for the Empowerment of State Apparatus and Birocracy Reform. (2009). Jabatan fungsional dan angka kredit guru no. 16. Jakarta: Author.

Suaib, N. R. A., \& Tohamba, C. P. P. (2017). Evaluation of reflective writing practice on preservice teachers: Systemic functional linguistics approach (Unpublished results). Retrieved from 
http://asiatefl2017.uny.ac.id/sites/asi atefl2017.../LIST\%20OF\%20ABSTR ACTS-Uploaded.pdf/.

Suherdi, D. (2012). Rekonstruksi pendidikan bahasa: Sebuah keniscayaan bagi keunggulan bangsa. Bandung: CELTICS Press.

Sze, P. (1999). Reflective teaching in second language teacher education: An overview. Educational Research Journal, 14(1), 131-155.

The Government of Republic of Indonesia. (2005). Standar nasional pendidikan. Jakarta, Indonesia: Author.

Tierney, W. G. (1988). Organizational culture in higher education: Defining the essentials. Journal of Higher Education, 59(1), 2-21.

Trites, L. (2010). Small-group journals as a tool of critical reflection: A measure of success and failure. In J. Burton, P. Quirke, C. L. Reichmann, \& J. K. Peyton (Eds.), Reflective writing: $A$ way to lifelong teacher learning (pp. 72-81). USA: TESL-EJ Publications.

United Nations Educational, Scientific, and Cultural Organization. (2016). Teachers in the Asia-Pacific: Career progression and professional development. France: Author.

Wang, J. (2011). Culture differences and English teaching. English Language Teaching, CCSENET, 4(2), 223-230.

Yeşilbursa, A. (2011). Descriptive versus dialogic reflection and positive versus negative stance in the reflective writing of Turkish prospective English language teachers. Novitas-ROYAL, Research on Youth and Language, 5(2),169182.

Zalipour, A. (2015). Reflective practice. New Zealand: The University of Waikato, Teaching Development Unit.

Zeichner, K. M., \& Liston, D. P. (1996). Reflective teaching: An introduction. Mahwah, NJ: Lawrence Erlbaum. 